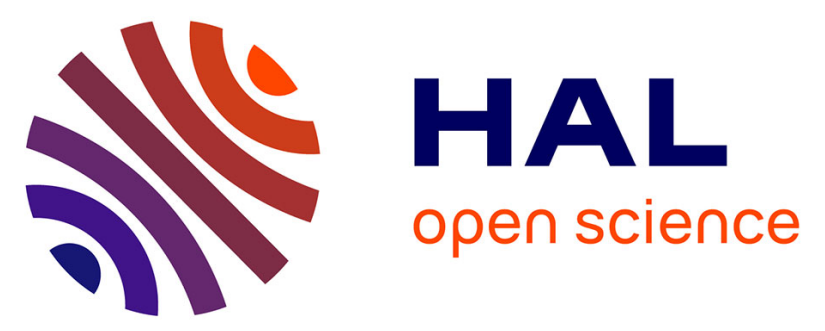

\title{
Mechanical and microstructural analysis of an EM10 wrapper tube after neutron irradiation in Phénix
}

\author{
Olivier Tissot, Pierre Gavoille, Benedicte Verhaeghe, Jean Henry
}

\section{To cite this version:}

Olivier Tissot, Pierre Gavoille, Benedicte Verhaeghe, Jean Henry. Mechanical and microstructural analysis of an EM10 wrapper tube after neutron irradiation in Phénix. Journal of Nuclear Materials, 2021, 543, pp.152575. 10.1016/j.jnucmat.2020.152575 . cea-03167157

\section{HAL Id: cea-03167157 https://hal-cea.archives-ouvertes.fr/cea-03167157}

Submitted on 11 Mar 2021

HAL is a multi-disciplinary open access archive for the deposit and dissemination of scientific research documents, whether they are published or not. The documents may come from teaching and research institutions in France or abroad, or from public or private research centers.
L'archive ouverte pluridisciplinaire HAL, est destinée au dépôt et à la diffusion de documents scientifiques de niveau recherche, publiés ou non, émanant des établissements d'enseignement et de recherche français ou étrangers, des laboratoires publics ou privés.

\section{(ㅇ)(1) $\$$}

Distributed under a Creative Commons Attribution - NonCommercial - NoDerivatives| 4.0 
Mechanical and microstructural analysis of an EM10 wrapper tube after neutron irradiation in Phénix

\author{
O. Tissot ${ }^{a *}$, P. Gavoille ${ }^{b}$, B. Verhaeghe ${ }^{b}$ and J. Henry ${ }^{a}$ \\ a Université Paris-Saclay, CEA, Service de Recherches Métallurgiques Appliquées, 91191, Gif-sur- \\ Yvette, France
}

${ }^{b}$ Université Paris-Saclay, CEA, Service d'Etudes des Matériaux Irradiés, 91191, Gif-sur-Yvette, France

\begin{abstract}
:
The $9 \mathrm{Cr}$-1Mo tempered martensitic steel was irradiated with fast neutrons in the French Phénix reactor. Mechanical tests, density measurement as well as microstructural investigations were carried out following irradiation up to $155 \mathrm{dpa}$ in the temperature range $386^{\circ} \mathrm{C}-525^{\circ} \mathrm{C}$. Tensile, elongation and impact properties were only slightly modified by irradiation. Microstructural investigations revealed the presence of cavities, however the resulting swelling was low (0.1\%). In most cases, the dislocation microstructure was arranged in a network. Nevertheless, some large loops were observed after irradiation at $398^{\circ} \mathrm{C}$ to 112 dpa. Overall, the EM10 steel showed excellent radiation resistance, which confirmed that this steel is an attractive wrapper candidate material for future sodium-cooled GEN IV fast reactors.
\end{abstract}

Key words: Ferritic/Martensitic, Neutron irradiation, EM10, Hexagonal Duct, Mechanical tests, Microstructural characterization.

\title{
1. Introduction
}

The $9 \mathrm{Cr}$-1Mo tempered martensitic steel (referred to as EM10 steel in France) is a candidate for application in future GEN IV reactors. In particular, its characteristics make it a reference material for the hexagonal duct of GEN IV SFR's (Sodium-cooled Fast Reactor) assemblies [1]. EM10 presents very good resistance to swelling up to $100 \mathrm{dpa}$ at least and exhibits dimensional stability up to $550^{\circ} \mathrm{C}[2,3]$. In addition, this material has good mechanical and thermal properties [4,5]. Owing to its relatively low $\mathrm{Cr}$ content (9at.\%), it is not subjected to hardening by the well-known $\alpha-\alpha^{\prime}$ decomposition, above $300^{\circ} \mathrm{C}$.

EM10 has been chosen as material for the hexagonal duct of the Phénix fuel assembly. Hexagonal ducts (or wrapper tubes) have been irradiated in Phénix to high doses. For instance, as part of the "Sphinx5" experiment, an EM10 wrapper tube has been irradiated to a maximum dose of $105 \mathrm{dpa}$. Density

* corresponding author (olivier.tissot@cea.fr) 
measurements and Transmission Electron Microscopy (TEM) investigations have revealed that irradiation-induced swelling was negligible [6]. However, significantly higher values for the end-of-life neutron exposure of hexagonal ducts, up to at least 150-200 dpa, are envisaged in the case of future GEN IV SFRs. Moreover, it has been argued that the excellent swelling resistance of Ferritic/Martensitic steels is mainly due to a long incubation period (transient regime) and that FM steels should eventually swell at a steady state swelling rate which could be as high as $0.2 \% / \mathrm{dpa}$ [3]. Therefore, the swelling behavior of EM10 must be investigated up to doses higher than the value obtained in Sphinx 5 in order to demonstrate that this steel can be used as wrapper material in future SFRs. To this end, a comprehensive program of Post-Irradiation Experiments (PIE) has been set up to characterize an EM10 hexagonal duct irradiated to $155 \mathrm{dpa}$ in Phénix (Boitix 9 experiment). The purpose of the present article is to describe the results of the Boitix 9 PIE, which consisted of mechanical tests (tensile and impact) density measurements, as well as TEM microstructural observations.

\section{Materials and methods}

\subsection{Materials and irradiation conditions}

The chemical composition of the EM10 steel used to fabricate the Boitix 9 hexagonal duct is reported in Table 1 (Steel Heat number HZ 9168-1, produced by “Aubert et Duval” company).

Table 1 : Chemical composition (in weight \%) of EM10 steel.

\begin{tabular}{cccccccccc}
\hline Elts & $\mathrm{C}$ & $\mathrm{Cr}$ & $\mathrm{Mo}$ & $\mathrm{Si}$ & $\mathrm{Mn}$ & $\mathrm{Ni}$ & $\mathrm{N}$ & $\mathrm{P}$ & $\mathrm{S}$ \\
\hline wt.\% & 0.096 & 8.80 & 1.09 & 0.37 & 0.51 & 0.18 & 0.024 & 0.015 & 0.005
\end{tabular}

During the fabrication of the duct, the final steps of the fabrication route were as follows:

- Austenitizing at $970^{\circ} \mathrm{C}$ for 30 minutes (in vacuum) followed by fast cooling to room temperature and tempering ( 30 minutes at $755^{\circ} \mathrm{C}$, in vacuum) ;

- $20 \%$ cold rolling ;

- Tempering ( 30 minutes at $755^{\circ} \mathrm{C}$, in vacuum).

The as-fabricated hexagonal duct had a span of $124 \mathrm{~mm}$ across each face and a wall thickness of 3.4 $\mathrm{mm}$. Boitix 9 fuel assembly, containing fuel pins clad with cold-worked 15-15 Ti austenitic stainless steel, was irradiated during 13 cycles in the Phénix fast reactor. This assembly accumulated an exposure of 1119 Equivalent Full Power Days (EFPD) over a period of approximately 10 years.

Dimensional measurements carried out after irradiation revealed that the deformation of the irradiated hexagonal duct was very small: no increase in length, the maximum increase of the flat width was estimated to be about $0.5 \%$, small bending of the irradiated duct and no evidence of bundle-duct interaction.

Following the dimensional measurements, the duct was cut and three flats out of six were sent to CEA Saclay hot labs. Flats 1 to 3 were examined as they were assumed to have been subjected to a low flux gradient. Plates were then machined out of the flats. For each plate, the irradiation conditions are considered to be constant. These conditions are given in Table 2, as a function of the axial position in 
the core. The values of irradiation temperatures are not measured data, but calculated values in the case of an EM10 duct irradiated in Phénix under nominal operating conditions (time averaged midwall). The total dose reached in the mid-core region was about $155 \mathrm{dpa}$, as can be seen in Figure 1 . The dpa rate is estimated to be at a maximum of $1.610^{-6} \mathrm{dpa} / \mathrm{s}$.

Table 2: Irradiation conditions of the EM10 Boitix9 hexagonal duct as a function of axial location in the core.

\begin{tabular}{|c|c|c|c|}
\hline \multirow{2}{*}{\multicolumn{2}{|c|}{$\begin{array}{c}\text { Axial core } \\
\text { position }(\mathrm{mm})\end{array}$}} & \multirow{3}{*}{$\begin{array}{c}\text { Irradiation } \\
\text { temperature }\left({ }^{\circ} \mathrm{C}\right) \\
386\end{array}$} & \multirow{3}{*}{$\begin{array}{c}\text { Dose (dpa) } \\
62\end{array}$} \\
\hline & & & \\
\hline Stage 7 & -441 & & \\
\hline Stage 8 & -311 & 398 & 112 \\
\hline Stage 9 & -181 & 414 & 141 \\
\hline Stage 10 & -51 & 439 & 155 \\
\hline Stage 11 & 79 & 467 & 149 \\
\hline Stage 12 & 209 & 488 & 127 \\
\hline Stage 14 & 469 & 525 & 43 \\
\hline
\end{tabular}

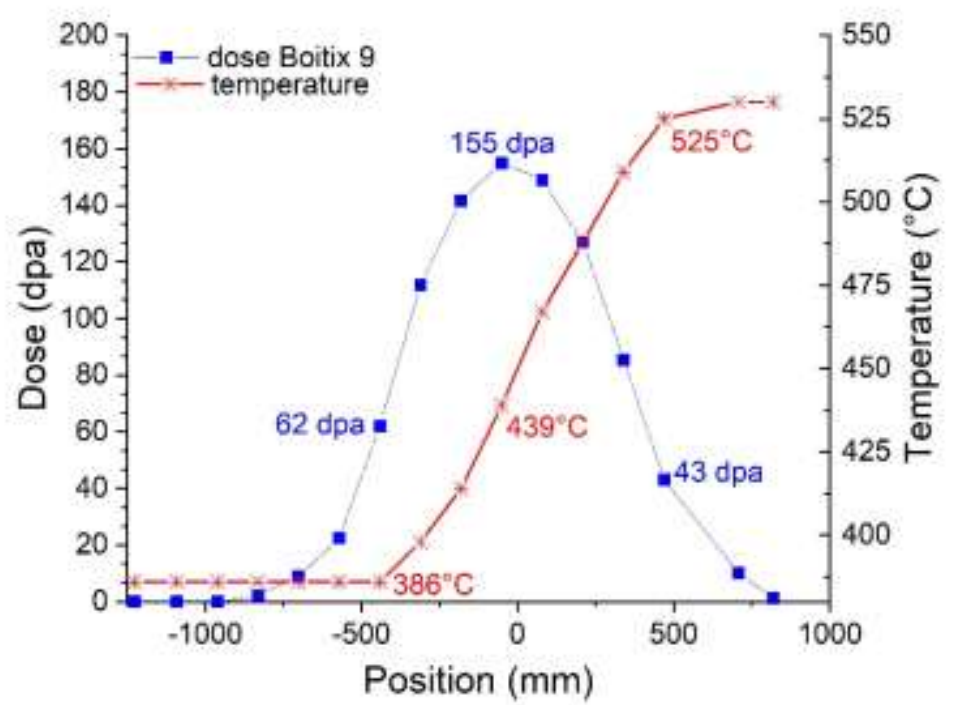

Figure 1: Irradiation conditions that were experienced by the Boitix 9 duct as a function of axial position in the core.

\subsection{Density measurements}

Density measurements were made by double weighing in air and in bromobenzene. Each measure was repeated three times. The samples had a geometry of $15 \times 20 \times 3.5 \mathrm{~mm}^{3}$. The scale used had a precision of $10^{-4} \mathrm{~g}$. The density was estimated using the following equation: 


$$
\rho=\frac{\left(M_{1}-m_{1}\right)}{\left(M_{1}-m_{1}\right)-\left(M_{2}-m_{2}\right)}\left(d_{\text {bromobenzene }}-d_{\text {air }}\right)+d_{\text {air }}
$$

With:

- $\quad \rho\left(\mathrm{g} / \mathrm{cm}^{3}\right)$ : density of the sample

- $M_{1}-m_{1}(g)$ : weight in the air

- $\quad \mathrm{M}_{2}-\mathrm{m}_{2}(\mathrm{~g})$ : weight in bromobenzene

- $d_{\text {bromobenzene }}\left(\mathrm{g} / \mathrm{cm}^{3}\right)$ : density of the liquid

- $d_{\text {air }}\left(\mathrm{g} / \mathrm{cm}^{3}\right)$ : density of the air

The swelling $(\mathrm{S})$ is then expressed as :

$$
S(\%)=\frac{V-V_{0}}{V_{0}} .100=\frac{d-d_{0}}{d_{0}} .100 \text { with } \mathrm{V}_{0} \text { and } \mathrm{d}_{0} \text { the volume and density before irradiation and }
$$
$\mathrm{V}$ and $\mathrm{d}$ after irradiation.

\subsection{Mechanical tests}

- $\quad$ Tensile test and Impact testing

Tensile and impact specimens were machined out of the Boitix9 wall plates by Electrical Discharge Machining (EDM). The tensile specimens were flat dogbone specimens, $34 \mathrm{~mm}$ long, $10 \mathrm{~mm}$ wide, with gauge dimensions of $7.5 \times 1.5 \mathrm{~mm}^{2}$, which were machined in T orientation (i.e. oriented perpendicular to the rolling direction). Their thickness was equal to the duct wall thickness $(3.4 \mathrm{~mm})$.

Two types of Charpy impact specimens were machined with TL orientation (i.e. Charpy specimen oriented perpendicular to the rolling direction, while crack propagation is parallel to the rolling direction):

1) Charpy specimens $55 \mathrm{~mm}$ long, $10 \mathrm{~mm}$ wide and $3.4 \mathrm{~mm}$ thick ;

2) Miniature Charpy specimens $27 \mathrm{~mm}$ in long, $4 \mathrm{~mm}$ in wide and $3.4 \mathrm{~mm}$ thick.

Tensile tests were carried out using an electromechanical machine with a $50 \mathrm{kN}$ load cell equipped with a furnace. Testing was performed under displacement control at an initial strain rate of $3 \times 10^{-4} / \mathrm{s}$, at three temperatures: Irradiation temperature, Room temperature (RT), and at $180^{\circ} \mathrm{C}$. Specimen heating to test temperature lasted for about 1 hour, and the specimens were kept at the selected temperature for at least 30 minutes prior testing. In a few cases, the fracture surface area was measured after testing using an optical microscope in order to determine the Reduction of Area (RA).

Impact tests were performed using two Zwick-Roell machines with a capacity of $50 \mathrm{~J}$ and $300 \mathrm{~J}$, respectively. Both machines are equipped with a temperature chamber operating from $-150^{\circ} \mathrm{C}$ up to $650^{\circ} \mathrm{C}$ and with an automatic specimen transfer system. The specimen temperature was measured in the chamber by a thermocouple. The temperature was adjusted using either liquid nitrogen injection or electric resistance heating. The time of transfer to the anvil was taken into account in order to insure that impact testing was performed at the chosen temperature. Charpy specimens were tested at a swing speed of $3.11 \mathrm{~m} / \mathrm{s}$ while the striker velocity was $3.9 \mathrm{~m} / \mathrm{s}$ in the case of the miniature Charpy specimens. The absorbed energy was obtained based on the measurement of the angle of rise with a high precision angular encoder. The lateral expansion was also measured after testing using pictures 
of the broken specimens (the two halves were characterized for better precision) obtained with an optical microscope.

The experimental values of absorbed energy/lateral expansion were adjusted using equation (2) in order to determine the parameters which characterize the impact transition curve: the upper shelf energy $\left(E_{2}\right)$, the lower shelf energy $\left(E_{1}\right)$ and the Ductile-to-Brittle Transition Temperature (DBTT).

$$
E=E_{1}+\frac{\left(E_{2}-E_{1}\right)}{2}\left[1+t h \frac{T_{\text {test }}-D B T T}{d T}\right]
$$

\subsection{Microstructural characterizations}

- Transmission Electron Microscopy

TEM thin foils of $3 \mathrm{~mm}$ diameter were made from the head of the tensile test sample. They were electro polished using a perchloric acid based electrolyte. Dislocation and cavity microstructures were characterized using a JEOL 2100 Transmission Electron Microscope (TEM) operating at 200kV and equipped with a $\mathrm{LaB}_{6}$ electron source. Cavities were imaged with underfocussed conditions of the objective lens (-1000nm or $-2000 \mathrm{~nm}$ ). A Gatan Imaging Filter (GIF Tridiem) was used to measure the sample thickness by electron energy loss spectrometry. Dislocation loop and void size distributions were determined using Visilog 7.0 image analysis software coupled to a Wacom Cintiq 21 type graphics tablet.

For the sake of simplicity, voids were assumed to be roughly spherical, and for each analyzed void, the value of the apparent diameter was measured. The void volume fraction $\mathrm{f}$ was then calculated as: $f=$

$\frac{\sum_{i} \frac{1}{6} \pi D_{i}^{3}}{V_{t}}$ where $D_{i}$ was the void diameter and $V_{t}$ the analyzed volume, which was determined based on the surfaces of the analyzed zones and their local thicknesses.

\section{Results and discussion}

\subsection{Density measurements}

Density measurement results are shown in Table 3. The estimated swelling (about $0.2 \%$ ) is low and there is no significant evolution up to about $120 \mathrm{dpa}$. A slight increase up to $0.3 \%$ was observed for the highest dose (149 dpa). 
Table 3: Density measurements of the EM10 alloys irradiated with neutrons in Phénix

\begin{tabular}{ccccc}
\hline Stage & $\begin{array}{c}\text { Irradiation } \\
\text { temperature }\left({ }^{\circ} \mathrm{C}\right)\end{array}$ & Dose (dpa) & Density (g/cm3) & Swelling (\%) \\
\hline 1 & 386 & 0 & 7.758 & 0.21 \\
3 & 386 & 1 & 7.754 & 0.26 \\
5 & 386 & 9 & 7.757 & 0.22 \\
7 & 386 & 62 & 7.755 & 0.24 \\
9 & 414 & 141 & 7.750 & 0.31 \\
11 & 467 & 149 & 7.753 & 0.27 \\
\hline
\end{tabular}

\subsection{Tensile tests}

All the tensile test data are listed in Table 4. In addition, tensile data for EM10 in the unirradiated condition, which had been measured at different temperatures (using the same sample geometry) as part of an earlier program, are reported in Table 5. As an example, Figure 2 shows the engineering stress-strain curves for the irradiated EM10 samples tested at RT. The tensile data measured at irradiation temperature and at room temperature are plotted in Figure 3 and 4.

These measurements have confirmed the good tensile behavior of EM10 both prior and after irradiation up to a high dose, in the temperature range $\left[385-525^{\circ} \mathrm{C}\right]$. This material retained rather high strength even when tested at $525^{\circ} \mathrm{C}$ (Ultimate Tensile Strength (UTS) values are above approximately $390 \mathrm{MPa}$ ). Moreover, for all irradiation and test conditions, the tested samples exhibited a fully ductile behavior, with significant necking and Uniform Elongation (UE) values greater than $1 \%$ (for the specimen geometry used in this experiment), as shown in Table 4 and Figure 3-4. 


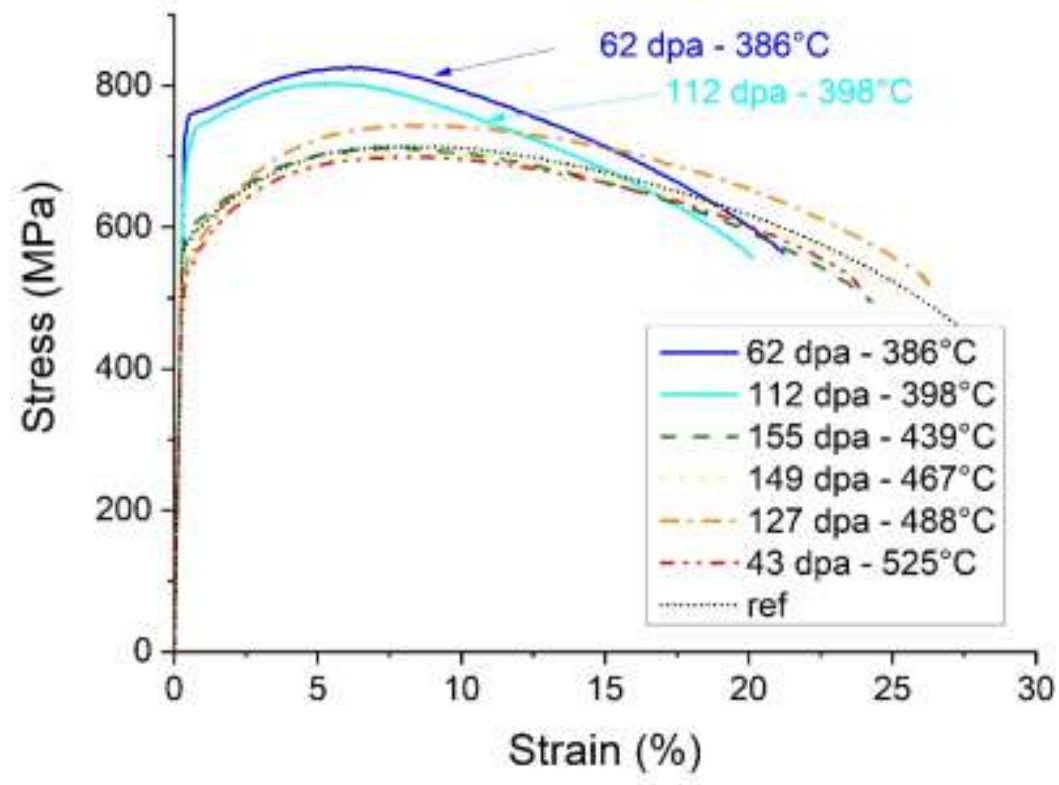

Figure 2: Engineering tensile curves for EM10 specimens extracted from Boitix9 hexagonal duct. The tests were performed at room temperature.

Table 4: Tensile properties measured on specimens extracted from Boitix9 EM10 wrapper tube irradiated to a maximum dose of $155 \mathrm{dpa}$. Values in blue were obtained at room temperature, in green at the irradiation temperature and in red at $180^{\circ} \mathrm{C}$.

\begin{tabular}{cccccccccc}
\hline $\begin{array}{c}\text { ID } \\
\text { Mark }\end{array}$ & $\begin{array}{c}\text { Axial } \\
\text { core } \\
\text { position } \\
\text { (stage) }\end{array}$ & dose & $\begin{array}{c}\mathbf{T}_{\text {irr }} \\
\left({ }^{\circ} \mathbf{C}\right)\end{array}$ & $\begin{array}{c}\mathbf{T}_{\text {test }} \\
\left({ }^{\circ} \mathbf{C}\right)\end{array}$ & $\begin{array}{c}\text { YS } \\
(\mathbf{M P a})\end{array}$ & $\begin{array}{c}\text { UTS } \\
\text { (MPa) }\end{array}$ & $\begin{array}{c}\text { UE } \\
(\%)\end{array}$ & $\begin{array}{c}\text { TE } \\
(\%)\end{array}$ & $\begin{array}{c}\text { RA } \\
(\%)\end{array}$ \\
\hline T14 & 14 & 43 & 525 & 20 & 527 & 700 & 8.42 & 23.57 & 51.2 \\
T2 & 7 & 62 & 386 & 20 & 759 & 826 & 5.79 & 20.93 & - \\
T5 & 8 & 112 & 398 & 20 & 716 & 804 & 4.87 & 19.88 & - \\
T17 & 12 & 127 & 488 & 24 & 554 & 745 & 8.29 & 26.01 & \\
T11 & 11 & 149 & 467 & 21 & 544 & 706 & 7.43 & 25.15 & - \\
T8 & 10 & 155 & 439 & 23 & 596 & 713 & 6.91 & 24.02 & 55.0 \\
T13 & 14 & 43 & 525 & 525 & 381 & 406 & 1.84 & 28.66 & 61.3 \\
T1 & 7 & 62 & 386 & 386 & 595 & 674 & 3.66 & 16.22 & - \\
T6 & 8 & 112 & 398 & 398 & 599 & 639 & 2.63 & 15.96 & - \\
T16 & 12 & 127 & 488 & 488 & 408 & 489 & 4.66 & 26.00 & - \\
T12 & 11 & 149 & 467 & 467 & 430 & 492 & 3.73 & 24.48 & - \\
T7 & 10 & 155 & 439 & 439 & 458 & 519 & 3.94 & 20.11 & 45.2 \\
T15 & 14 & 43 & 525 & 180 & 484 & 610 & 6.76 & 22.38 & - \\
T3 & 7 & 62 & 386 & 180 & 680 & 741 & 4.28 & 18.25 & - \\
T4 & 8 & 112 & 398 & 180 & 660 & 716 & 3.90 & 17.64 & - \\
T18 & 12 & 127 & 488 & 180 & 480 & 654 & 6.38 & 22.97 & - \\
T10 & 11 & 149 & 467 & 180 & 486 & 621 & 6.67 & 23.33 & - \\
T9 & 10 & 155 & 439 & 179 & 530 & 618 & 5.45 & 20.76 & - \\
\hline & & & & & & & & & \\
\hline
\end{tabular}


Table 5: Tensile properties of EM10 in the unirradiated condition measured at different test temperatures. The sample geometry was identical to that used in the case of Boitix9 samples.

\begin{tabular}{ccccc}
\hline $\begin{array}{c}\mathbf{T}_{\text {test }} \\
\left({ }^{\circ} \mathbf{C}\right)\end{array}$ & $\begin{array}{c}\text { YS } \\
(\mathbf{M P a})\end{array}$ & $\begin{array}{c}\text { UTS } \\
(\mathbf{M P a})\end{array}$ & $\begin{array}{c}\text { UE } \\
(\%)\end{array}$ & $\begin{array}{c}\text { TE } \\
(\%)\end{array}$ \\
\hline 20 & 528 & 691 & 9.4 & 30.6 \\
200 & 483 & 615 & 7.9 & 25.5 \\
400 & 456 & 556 & 6.2 & 23.4 \\
450 & 425 & 508 & 5,0 & 26.5 \\
500 & 357 & 391 & 1.9 & 35.7 \\
550 & 356 & 386 & 1.6 & 34.3 \\
650 & 177 & 211 & 3.6 & 44.1 \\
\hline
\end{tabular}

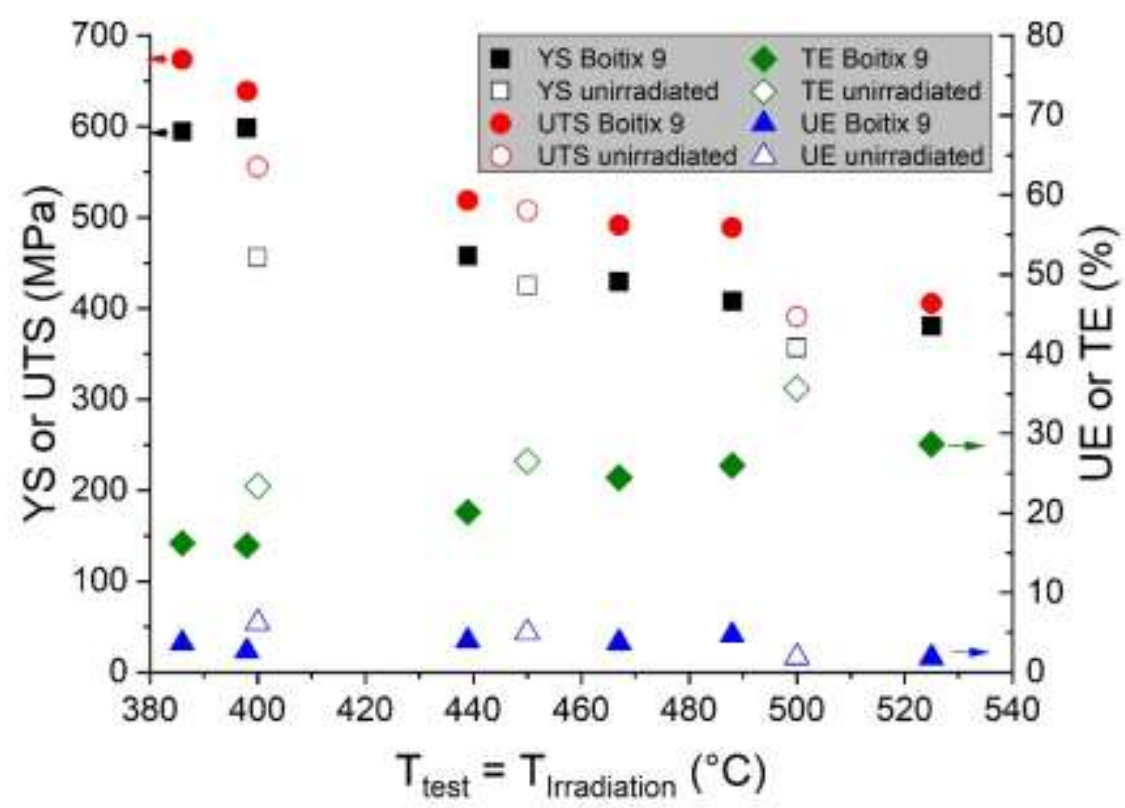

Figure 3: Evolution of the yield stress at $0.2 \%$ plastic strain (YS), ultimate tensile strength, (UTS), uniform and total elongations (UE, TE) as a function of irradiation temperature (tests performed at the same temperature) in EM10 alloy. 


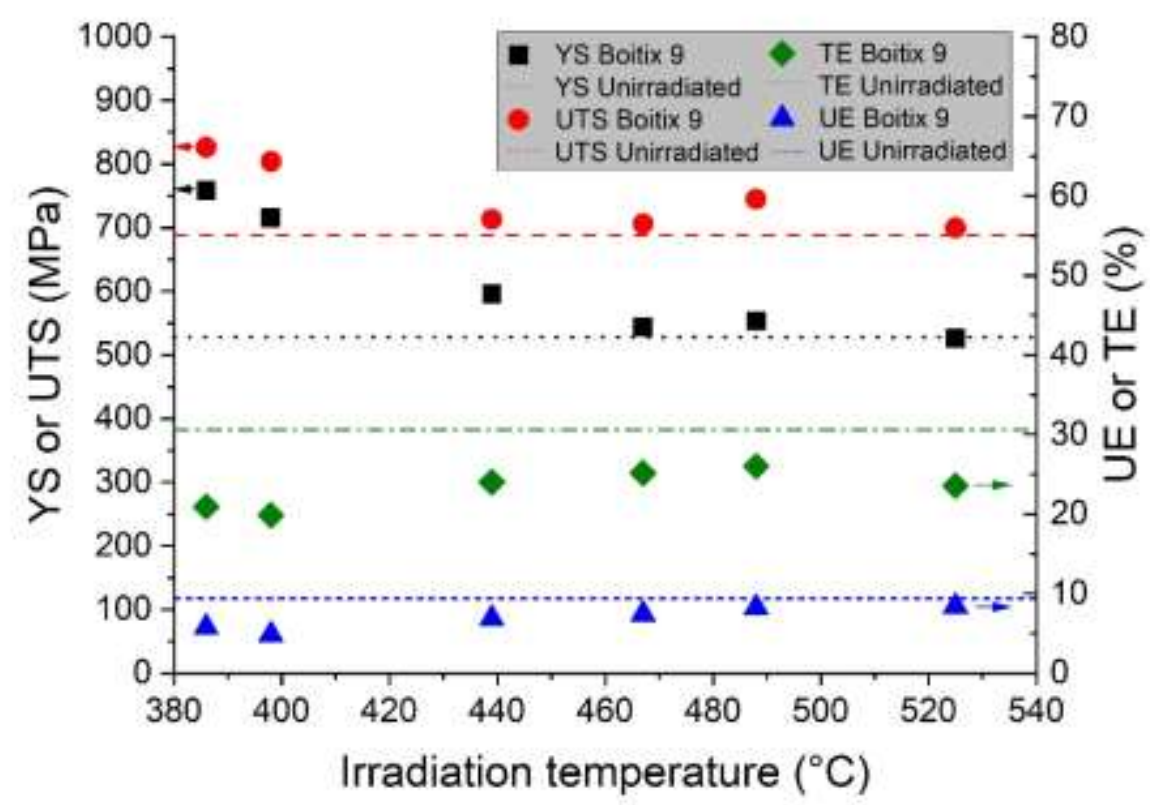

Figure 4: Evolution of the yield stress at $0.2 \%$ plastic strain (YS), ultimate tensile strength, (UTS), uniform and total elongations (UE, TE) as a function of irradiation temperature (tests performed at room temperature) in EM10 alloy.

In the irradiation temperature range of the Boitix 9 wrapper tube $\left(440^{\circ} \mathrm{C}\right)$, the effect of irradiation on the tensile properties is on the whole not very pronounced. It depends primarily on the irradiation temperature, as shown in Figure 5 -6 (in both figures, tensile data corresponding to "Sphinx5" PIE are also plotted as well as results of tensile tests performed on EM10 samples irradiated at $325^{\circ} \mathrm{C}$ [7-9]).

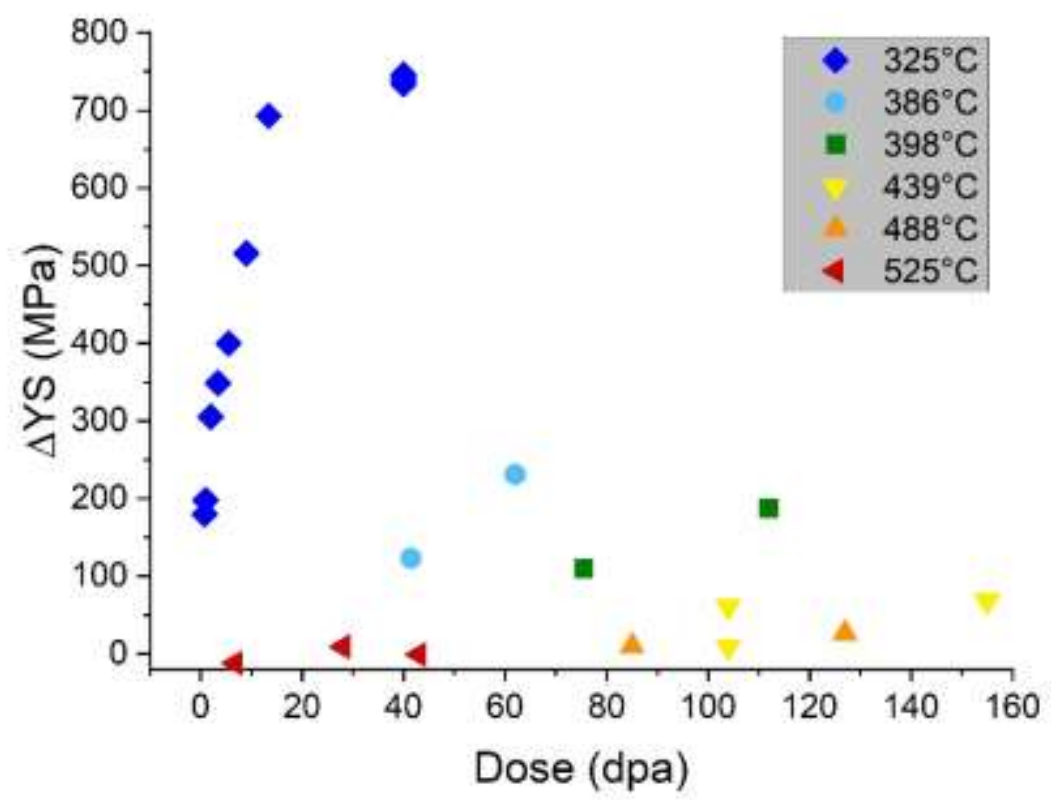

Figure 5: Radiation-induced hardening as a function of irradiation dose. In addition to Boitix 9 data, data points corresponding to tensile tests performed on specimens machined using the "Sphinx 5" hexagonal duct and on EM10 specimens irradiated at $325^{\circ} \mathrm{C}$ (Altair [7] and Alexandre [8,9] experiments) are also plotted. 
Based on the available data, for irradiation temperatures equal or above approximately $440^{\circ} \mathrm{C}$, no effect of irradiation is observed on the tensile properties, although the irradiation doses are high. Strength (YS, UTS) and ductility (TE, UE) are almost identical prior and after irradiation. In the lower irradiation temperature range for a Phénix EM10 wrapper tube $\left[385-400^{\circ} \mathrm{C}\right]$, a slight but significant effect is observed: increases in YS and UTS of about 100-200 MPa are measured after irradiation compared to the reference condition, while there is a slight decrease of the values of UE and TE. However, at lower irradiation temperature, the effect of irradiation on the tensile properties is much more pronounced as shown in Figures $5-6$. At $325^{\circ} \mathrm{C}$, a very large irradiation-induced hardening is measured, which reaches more than $700 \mathrm{MPa}$ for a dose of about $40 \mathrm{dpa}$, together with a drastic decrease of ductility (see Figure 6). These modifications of the tensile behavior are of course related to irradiation-induced changes in the microstructure (such as the formation of dislocation loops), which strongly depend on the irradiation temperature as discussed below.

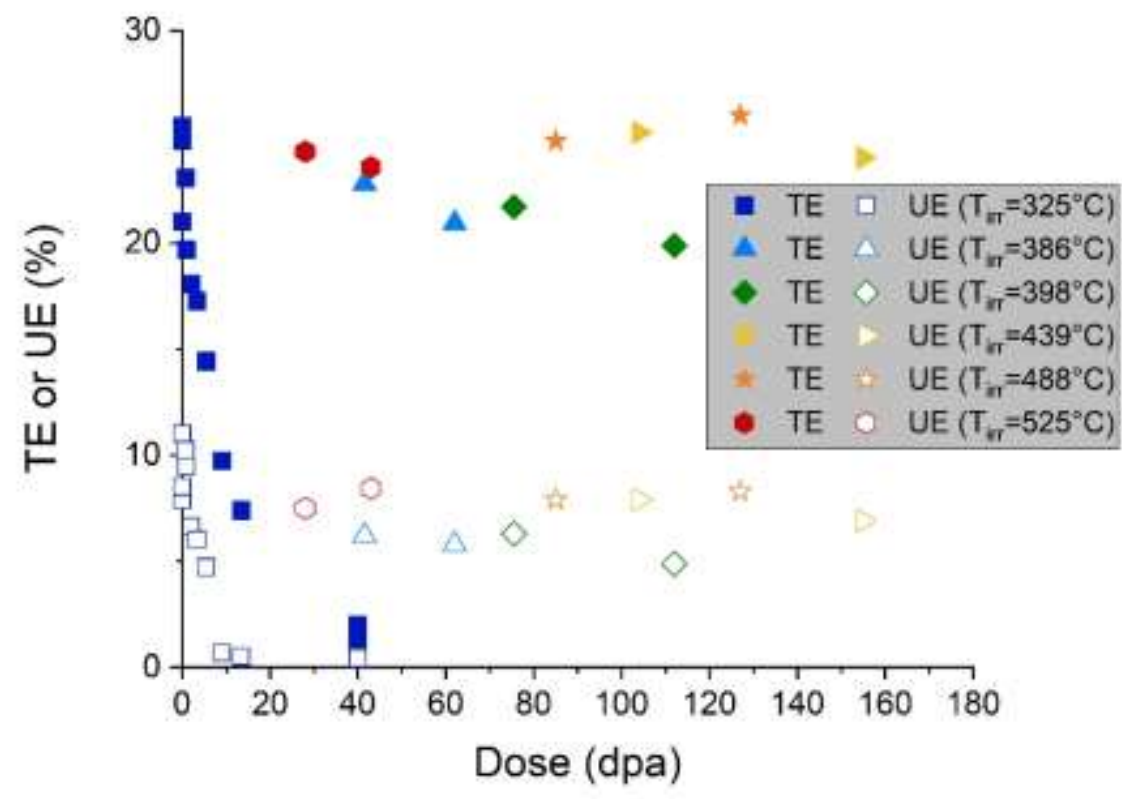

Figure 6: Evolution of the uniform and total elongations (UE, TE) as a function of irradiation dose. In addition to Boitix 9 data, data points corresponding to tensile tests performed on specimens machined using the "Sphinx 5" hexagonal duct and on EM10 specimens irradiated at $325^{\circ} \mathrm{C}$ (Altair [5] and Alexandre [6-7] experiments) are also plotted.

SEM fracture surface examinations were carried out on T1, T6 and T7 tensile samples (see Table 4). An example is shown in Figure $7\left(\mathrm{~T} 6=112 \mathrm{dpa}\right.$ and $\left.386^{\circ} \mathrm{C}\right)$. The fractographies show the absence of fragile features, such as intergranular facets. The fracture surface exhibits a fully ductile transgranular appearance with fine dimples $(<1 \mu \mathrm{m})$ (Figure 7). Nevertheless, it can be mentioned that some bigger dimples $(>10 \mu \mathrm{m})$ were also observed especially in the case of T1 and T6. 


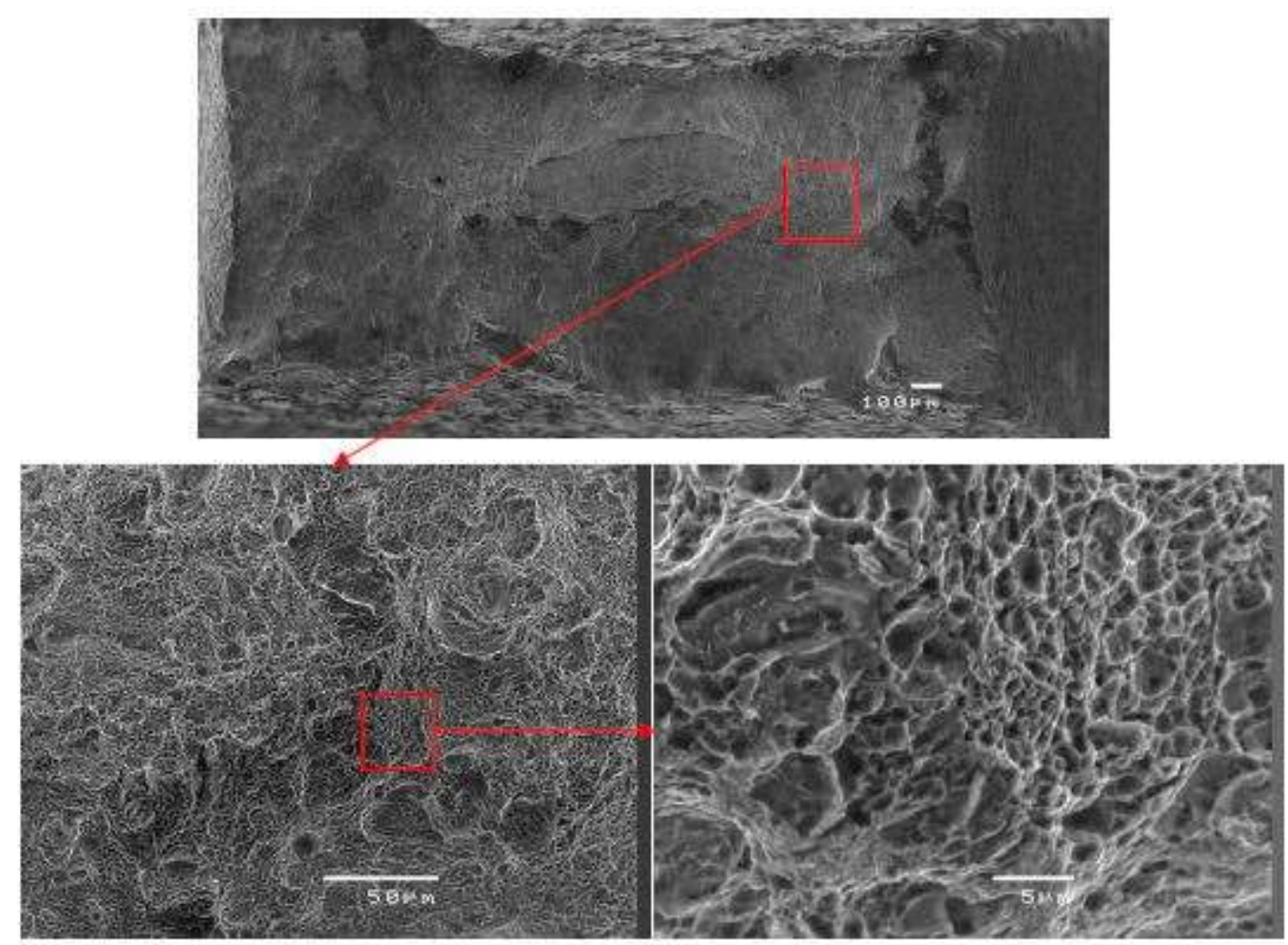

Figure 7: SEM of the fracture surface of EM10 irradiated to $112 \mathrm{dpa}$ at $386^{\circ} \mathrm{C}$.

\subsection{Impact tests}

Impact tests were carried out at temperatures ranging from $-150^{\circ} \mathrm{C}$ up to $200^{\circ} \mathrm{C}$ in order to determine the full temperature transition curves. Figure 8-10 present absorbed energy versus test temperature plots for different irradiation conditions. For instance Figure 8 is showing the impact curves for the two lowest irradiation temperatures investigated in this study, which are compared with a reference curve. This reference curve was not measured on as-received EM10 steel but using specimens extracted from the lower part of the Boitix 9 duct and which were aged at about $386^{\circ} \mathrm{C}$ but not subjected to neutron irradiation.

The two transition curves are almost identical for the two selected irradiation conditions and exhibit changes when compared with the reference curve. First, a decrease of the upper shelf energy, of about $9 \mathrm{~J}$, is observed. Furthermore, irradiation induced shifts of the transition curves to higher temperatures. In both cases, the ductile-to-brittle transition temperature (defined as the temperature corresponding to the average of upper shelf and lower shelf energies) was increased by about $45^{\circ} \mathrm{C}$. For higher irradiation temperatures, irradiation-induced changes of the transition curves were also observed, but were less pronounced than at lower temperatures. For instance, for the specimens irradiated at $467^{\circ} \mathrm{C}$, a very small decrease of upper shelf energy was measured (less than $3 \mathrm{~J}$ ) while the DBTT was shifted by $32^{\circ} \mathrm{C}$. These modifications are consistent with the smaller irradiation-induced hardening with increasing irradiation temperatures. 


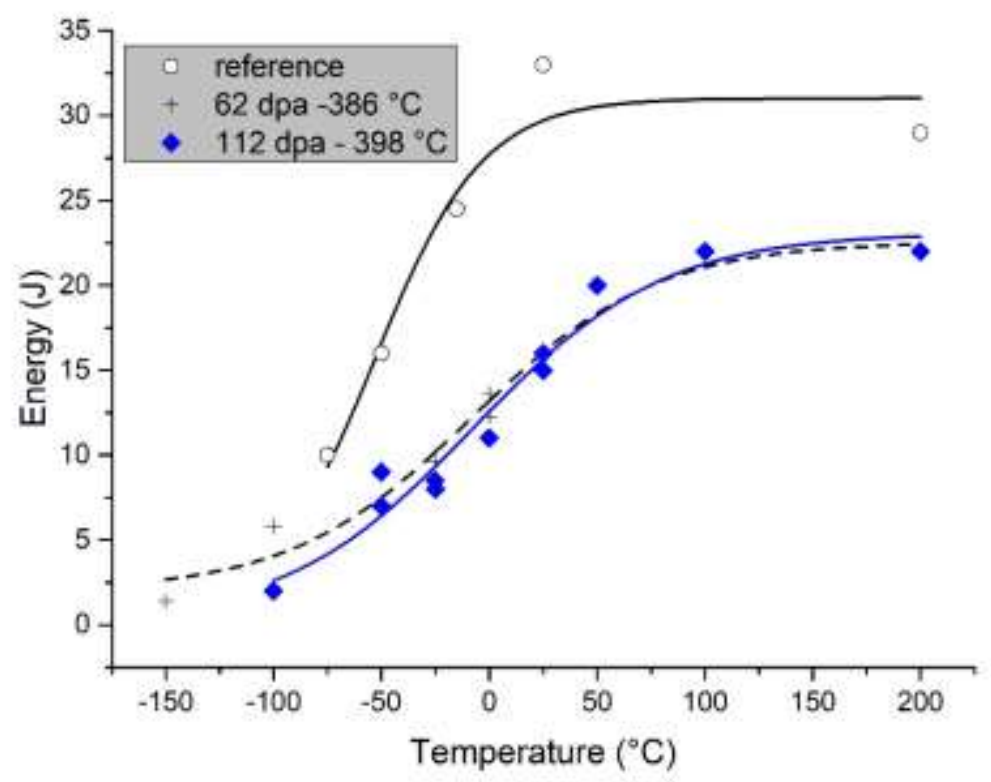

Figure 8: Charpy impact curves for specimens irradiated at 386 and $398^{\circ} \mathrm{C}$. The reference curve was obtained using specimens extracted from the lowest part of Boitix9 hexagonal duct (stage 1, no irradiation)).

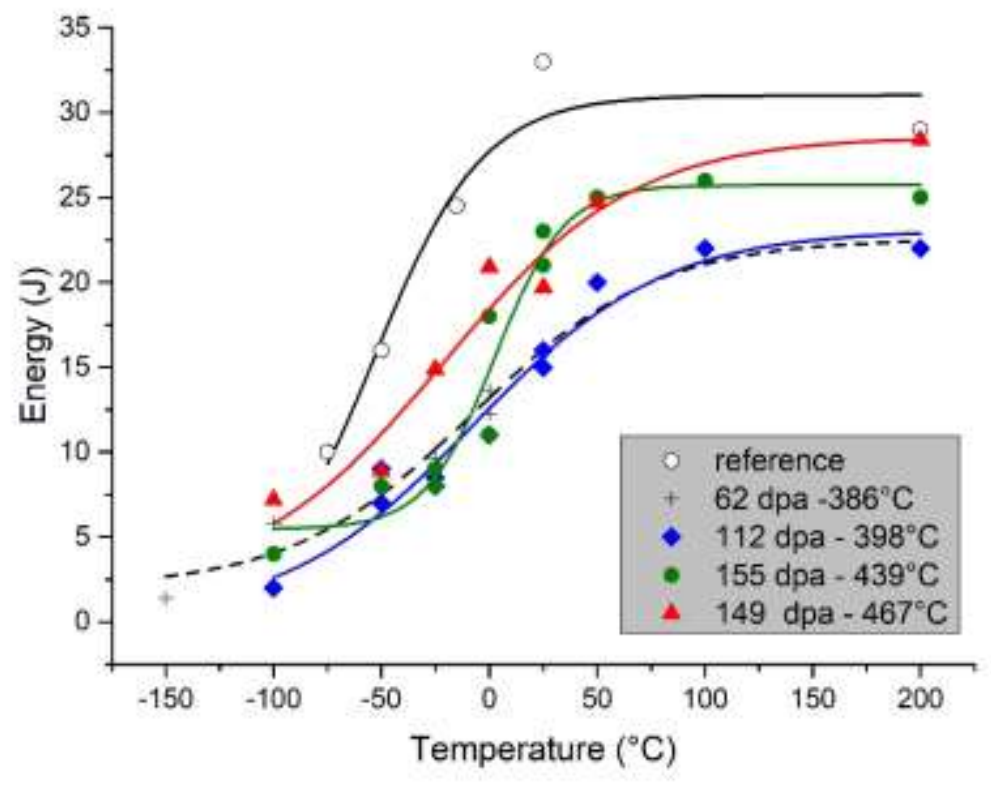

Figure 9: Charpy impact curves for specimens irradiated in the range [386- $\left.467^{\circ} \mathrm{C}\right]$.

However, for the highest irradiation temperatures, for which no irradiation-induced hardening occurred, impact curves exhibited changes compared to the reference case, which were comparable to the modifications observed in the case of the lowest irradiation temperatures. 


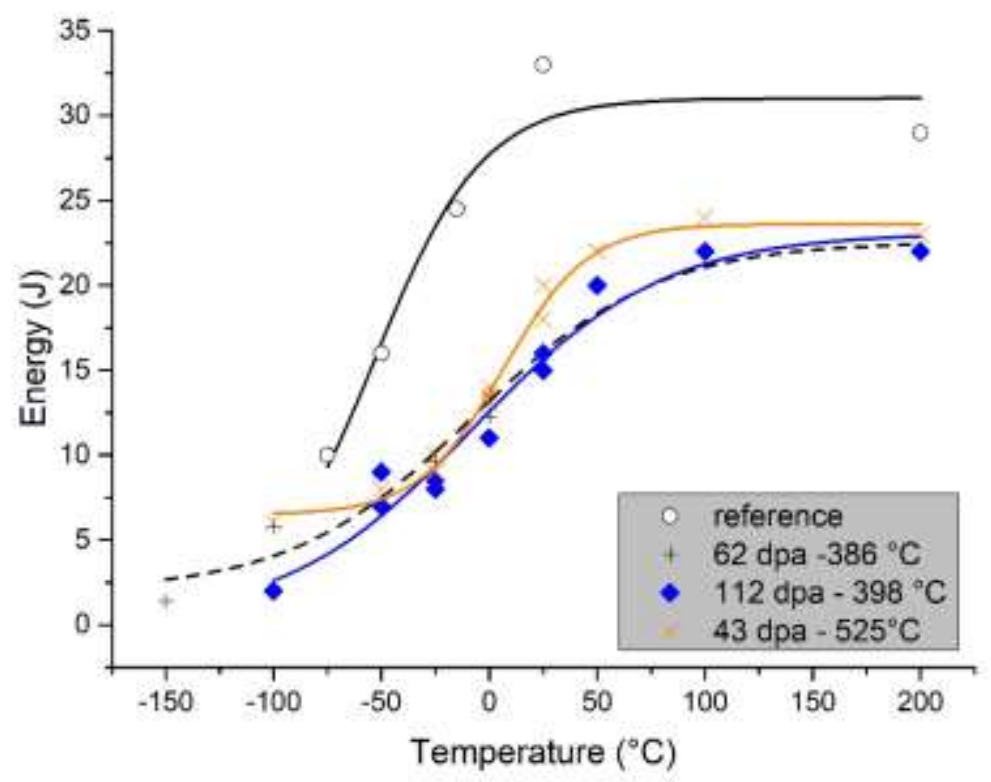

Figure 10: Charpy impact curves for specimens irradiated at $386,398^{\circ} \mathrm{C}$ and $525^{\circ} \mathrm{C}$.

This degradation of impact properties for specimens irradiated in the upper temperature range is probably due to a thermal ageing effect, rather than induced by irradiation. Indeed, impact tests performed on $9 \mathrm{Cr}$ martensitic steels (EM10 and T91 in particular), have shown that long term ageing (typically more than $1000 \mathrm{~h}$ ageing time) in the temperature range [500-550] induced a decrease of the upper shelf energy and a DBBT shift [10-13]. Furthermore, these changes became more pronounced with increasing ageing time. It is believed that these modifications were due to the precipitation of Laves phase $\left(\mathrm{Fe}_{2} \mathrm{Mo}\right)$, in particular on prior austenite grain boundaries and on martensite lath boundaries. For instance, a high density of rather large $\mathrm{Fe}_{2} \mathrm{Mo}$ precipitates with a platelet morphology was observed in EM10 irradiated to $24 \mathrm{dpa}$ at $525^{\circ} \mathrm{C}$ [14]. By contrast, long term ageing studies (up to $20000 \mathrm{~h}$ ) of EM10 steel at $300-450^{\circ} \mathrm{C}$ did not reveal any microstructural evolution and in particular the presence of Laves phase was not detected [13].

The values of DBTT measured on specimens extracted both from Sphinx5 and Boitix9 wrapper tubes are plotted against irradiation temperature in Figure 11 . In the temperature range $\left[385-525^{\circ} \mathrm{C}\right]$, no temperature dependence was found. The important result which deserves to be underlined is the fact that DBTT shifts remained rather moderate for Boitix9 irradiation conditions, ranging from about 30 to $59{ }^{\circ} \mathrm{C}$, in spite of the very high doses. At lower irradiation temperatures however, very high DBTT shifts were measured on EM10 and T91 irradiated in BOR60 [5,7], which is consistent with the huge hardening measured after irradiation. 


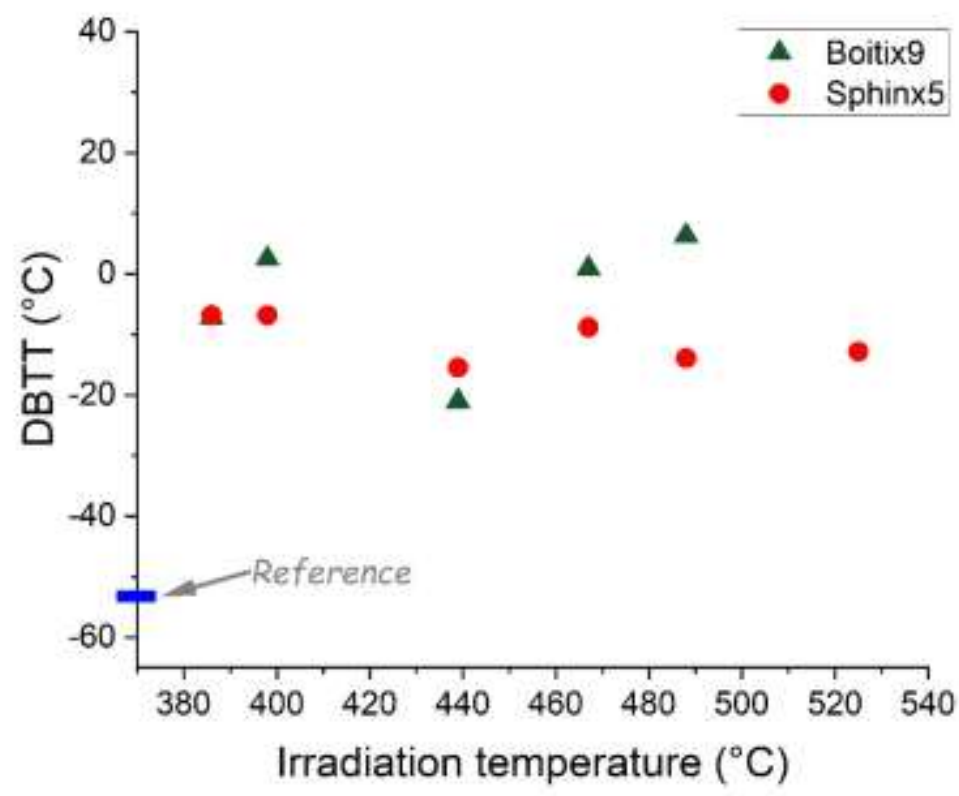

Figure 11: Ductile-to-Brittle Transition Temperature as a function of irradiation temperature. Boitix9 and Sphinx5 data are included in the plot.

Also, it can be noted that in the range $\left[385-525^{\circ} \mathrm{C}\right], \mathrm{EM} 10$ displayed a better impact behavior than other FM steels containing higher $\mathrm{Cr}$ contents. For instance, impact test performed on ACO-3 duct material (HT-9, a Fe-12Cr alloy) irradiated in the Fast Flux Test Facility (FFTF) to a maximum dose of $155 \mathrm{dpa}$, revealed rather high DBTT shifts after irradiation, of about $250^{\circ} \mathrm{C}$ for irradiation temperatures close to $380^{\circ} \mathrm{C}$, down to more than $80^{\circ} \mathrm{C}$ for the highest irradiation temperatures (about $500^{\circ} \mathrm{C}$ ) [15]. This different behavior compared to EM10 may be due to $\alpha^{\prime}$ precipitation in HT9, which would lead to additional hardening and embrittlement, particularly in the lower irradiation temperature range, close to $380^{\circ} \mathrm{C}$.

SEM observations of the fracture surfaces were carried out on stage $7\left(62 \mathrm{dpa}, 386^{\circ} \mathrm{C}\right)$ and $12(127 \mathrm{dpa}$, $\left.488^{\circ} \mathrm{C}\right)$ samples tested at $0^{\circ} \mathrm{C}$ and on stage $11\left(149 \mathrm{dpa}, 467^{\circ} \mathrm{C}\right)$ sample tested at $-25^{\circ} \mathrm{C}$. These samples were selected since they were tested at temperatures close to the DBTT for their respective irradiation conditions. Macroscopic morphologies were quite similar. A transgranular ductile fracture zone with dimples located behind the notch root with secondary cracks was noticed. Then, a transgranular cleavage fracture zone and finally a ductile propagation zone close to specimen edges were observed (Figure 12).

On Figure 12, we can observe many secondary cracks (Figure 12 (31c)) in the direction of the fracture propagation and then the brittle cleavage fracture propagation zone. This zone is surrounded by a ductile zone. The first zone, near the notch, showed a ductile transgranular surface with dimples (Figure $12(31 \mathrm{~b}))$. The initiation close to the notch was relatively planar without secondary cracks. Next, the propagation took place with many secondary cracks located in the central part of the fracture and in the propagation axis. No precipitates were observed in the cracks. Due to numerous cracks, it was difficult to determine the fracture initiation point. Nevertheless, we can guess that failure initiation occurred by cleavage in the axis of the fracture (Figure 12 (31d)) and just after the ductile zone. 


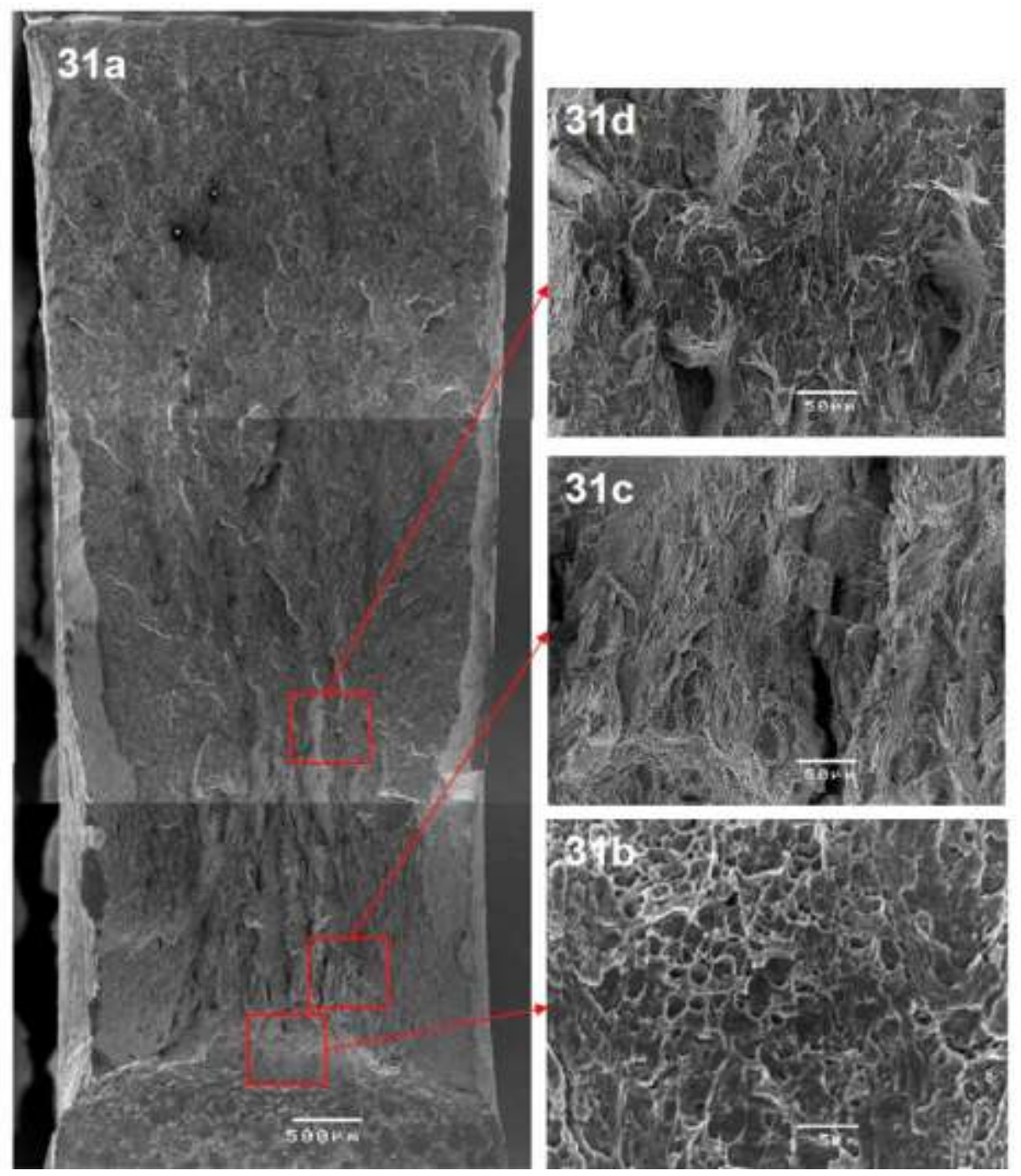

Figure 12: (31a) General view of the fracture surface of the impact test sample $T 7$ ( $62 \mathrm{dpa}$ and $\left.386^{\circ} \mathrm{C}\right)$ of the EM10 alloy irradiated with fast neutrons and tested at $0^{\circ} \mathrm{C}$. (31b) Ductile zone in the notch root. (31c) Secondary cracks. (31d) Initiating zone of brittle fracture.

\subsection{TEM microstructural characterizations}

Dislocation and void microstructures were characterized after irradiation under the following conditions: $386^{\circ} \mathrm{C}-62 \mathrm{dpa}, 398^{\circ} \mathrm{C}-112 \mathrm{dpa}, 439^{\circ} \mathrm{C}-155 \mathrm{dpa}$ and $525^{\circ} \mathrm{C}-43 \mathrm{dpa}$. The observations are presented in the following subsection.

- Dislocation microstructure

Figure 13 is showing the dislocation microstructure of the EM10 alloy irradiated under two different conditions. In Figure 13 a) corresponding to $62 \mathrm{dpa}$ and $386^{\circ} \mathrm{C}$, the microstructure consists of a dislocation network. This microstructure is representative of the $439^{\circ} \mathrm{C}-155 \mathrm{dpa}$ and $525^{\circ} \mathrm{C}-43 \mathrm{dpa}$ irradiations conditions. For the $112 \mathrm{dpa}$ and $398^{\circ} \mathrm{C}$ irradiation condition, large dislocation loops were seen in addition to the network (Figure $13 \mathrm{~b}$ )). The loop size (apparent diameter) distribution is 
depicted in Figure 14. The mean value for the apparent loop diameter was found to be $58 \mathrm{~nm}$. This value should be viewed cautiously due to the relatively low number of analyzed loops ( 89 loops).

Furthermore, the Burgers vector of some dislocation loops found in one zone of the sample was determined. Loops with Burgers vectors $b=a_{0}<100>$ and $b=1 / 2 a_{0}<111>$ were identified (see Figure $13 \mathrm{~b})$ ). Again, this analysis performed on a low number of loops has to be taken with caution and cannot provide an accurate value for the relative proportions of both types of loops. It is known that the amount of $<100>$ type loops increases with increasing irradiation temperature in iron, $\mathrm{FeCr}$ alloys and FM steels $[16,17]$.

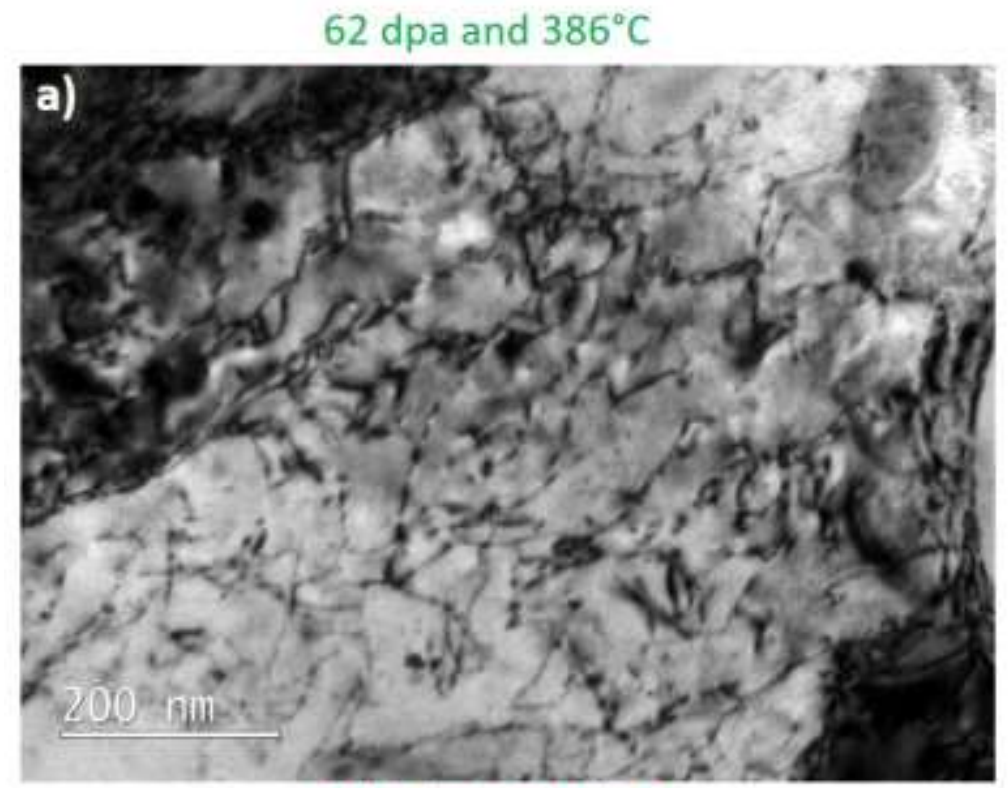

$112 \mathrm{dpa}$ and $398^{\circ} \mathrm{C}$

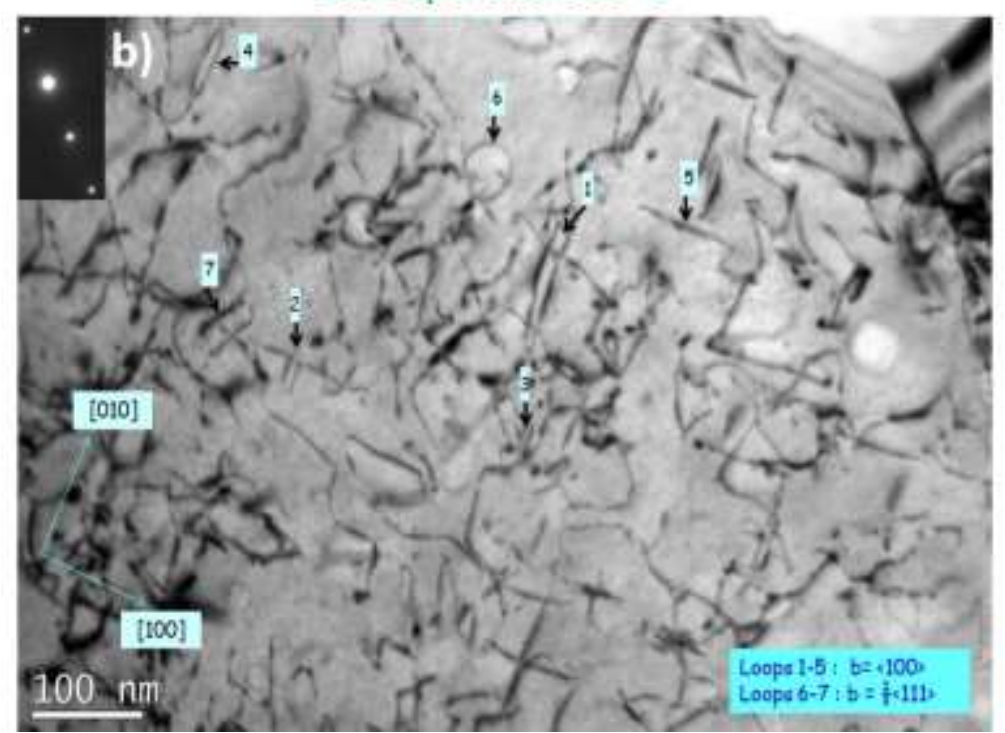

Figure 13: Dislocation microstructure of the EM10 alloy irradiated with neutrons at a) $62 \mathrm{dpa}$ and $386^{\circ} \mathrm{C}$ and b) $112 \mathrm{dpa}$ and $398^{\circ} \mathrm{C}$. The microstructures were observed under two beam imaging condition $g\{110\}$. 


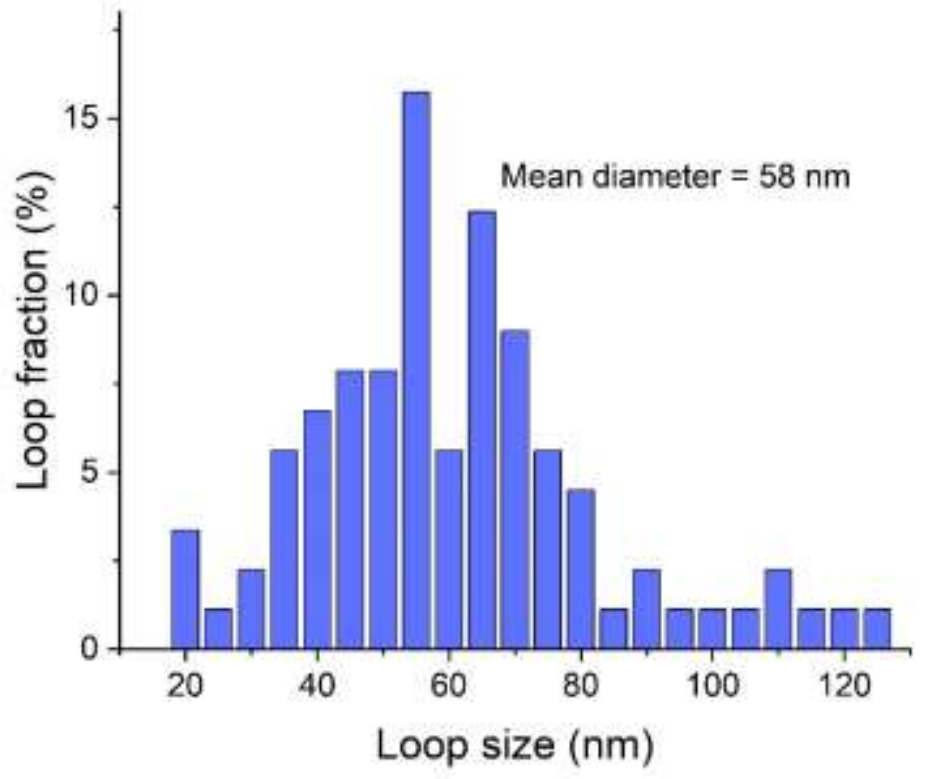

Figure 14: Dislocation loop size distribution in EM10 irradiated to 112 dpa at $398^{\circ} \mathrm{C}$

The dislocation densities were determined for the four investigated irradiation conditions based on TEM micrographs obtained in two beam diffraction conditions ( $\{110\}$ type diffraction vector), without trying to take into account possible extinctions of dislocation contrast depending on their Burgers vector. The obtained values are reported in the Table 6.

Table 6: Dislocation densities of the EM10 alloys irradiated in four different irradiation conditions.

\begin{tabular}{cc}
\hline Irradiation condition & Dislocation density $\left(\mathrm{cm}^{-2}\right)$ \\
\hline $62 \mathrm{dpa}$ and $386^{\circ} \mathrm{C}$ & $(3.4 \pm 1.1) 10^{+10}$ \\
$112 \mathrm{dpa}$ and $398^{\circ} \mathrm{C}$ & $(2 \pm 0.7) 10^{+10}$ \\
$155 \mathrm{dpa}$ and $439^{\circ} \mathrm{C}$ & $(8 \pm 2.7) 10^{+9}$ \\
$43 \mathrm{dpa}$ and $525^{\circ} \mathrm{C}$ & $(1.7 \pm 0.6) 10^{+10}$ \\
\hline
\end{tabular}

The values show that the dislocation density increased with decreasing irradiation temperature. This is qualitatively consistent with the fact that the yield stress of EM10 increased by about $160 \mathrm{MPa}$ when the irradiation temperature decreased from $439^{\circ} \mathrm{C}$ to $386^{\circ} \mathrm{C}$. Note that between $439^{\circ} \mathrm{C}$ and $525^{\circ} \mathrm{C}$, a slight density increase was measured. This was thought to be insignificant due measurement uncertainties. 
- Void microstructure

In EM10 irradiated to $43 \mathrm{dpa}$ at $525^{\circ} \mathrm{C}$, very few cavities were observed and no quantification was carried out. For the three other conditions, the presence of cavities was detected and quantified. As shown by the low magnification TEM micrograph Figure 15, the distributions of cavities were found to be heterogeneous. Although, due to variations in the orientations of the different grains and martensite laths, the conditions are not everywhere optimized for suitable imaging of voids, one can nevertheless notice that in some areas hardly any void can be detected, while in other areas void densities are significantly higher.

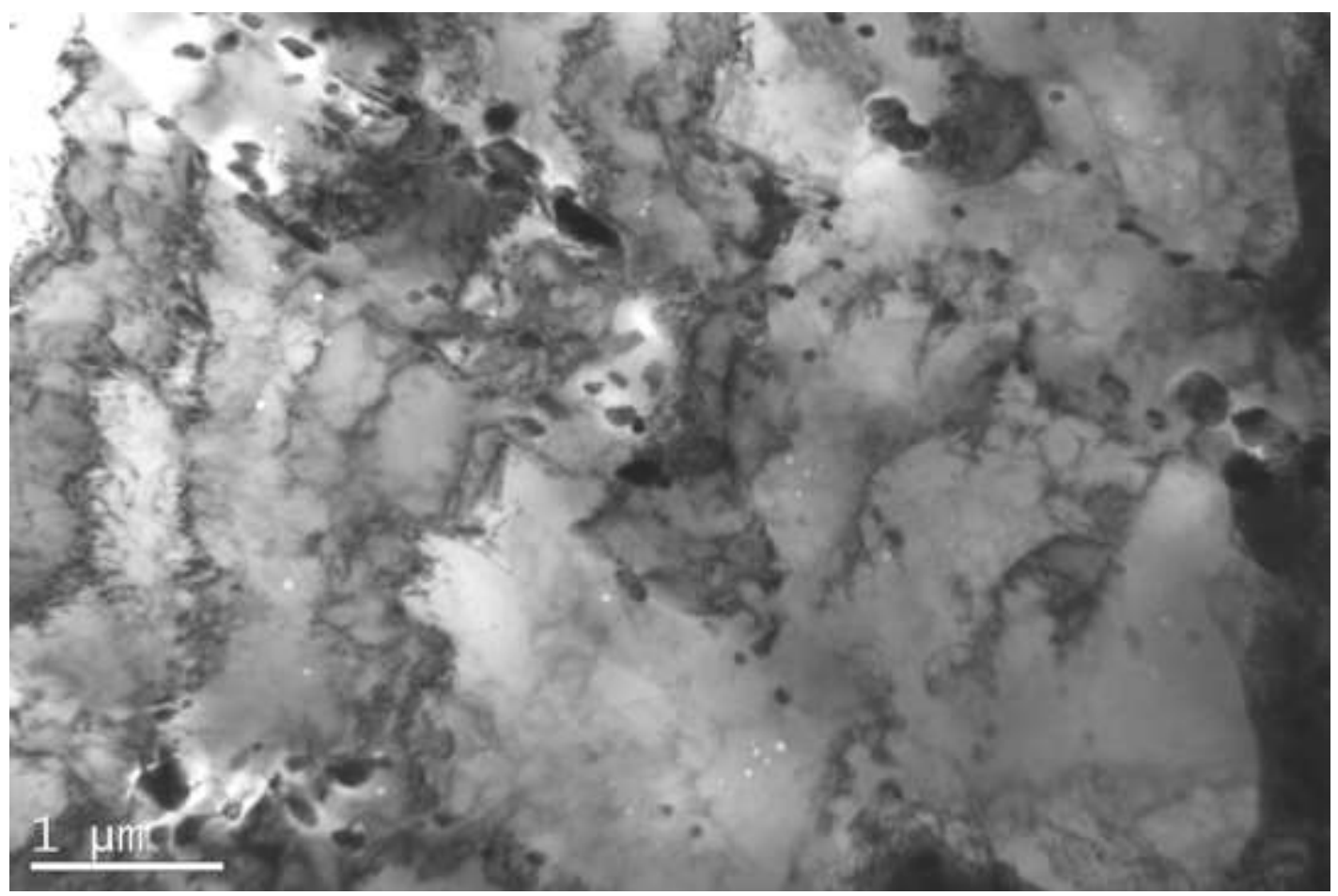

Figure 15: Low magnification TEM micrograph showing the heterogeneous void distribution in EM10 alloy irradiated to 155 dpa at about $439^{\circ} \mathrm{C}$.

The cavities have a facetted morphology (Figure 16 - Figure 17). In the case of EM10 irradiated at $398^{\circ} \mathrm{C}$, most voids were found to have a cubic shape, with faces parallel to $\{100\}$ planes, as shown in Figure 16. 


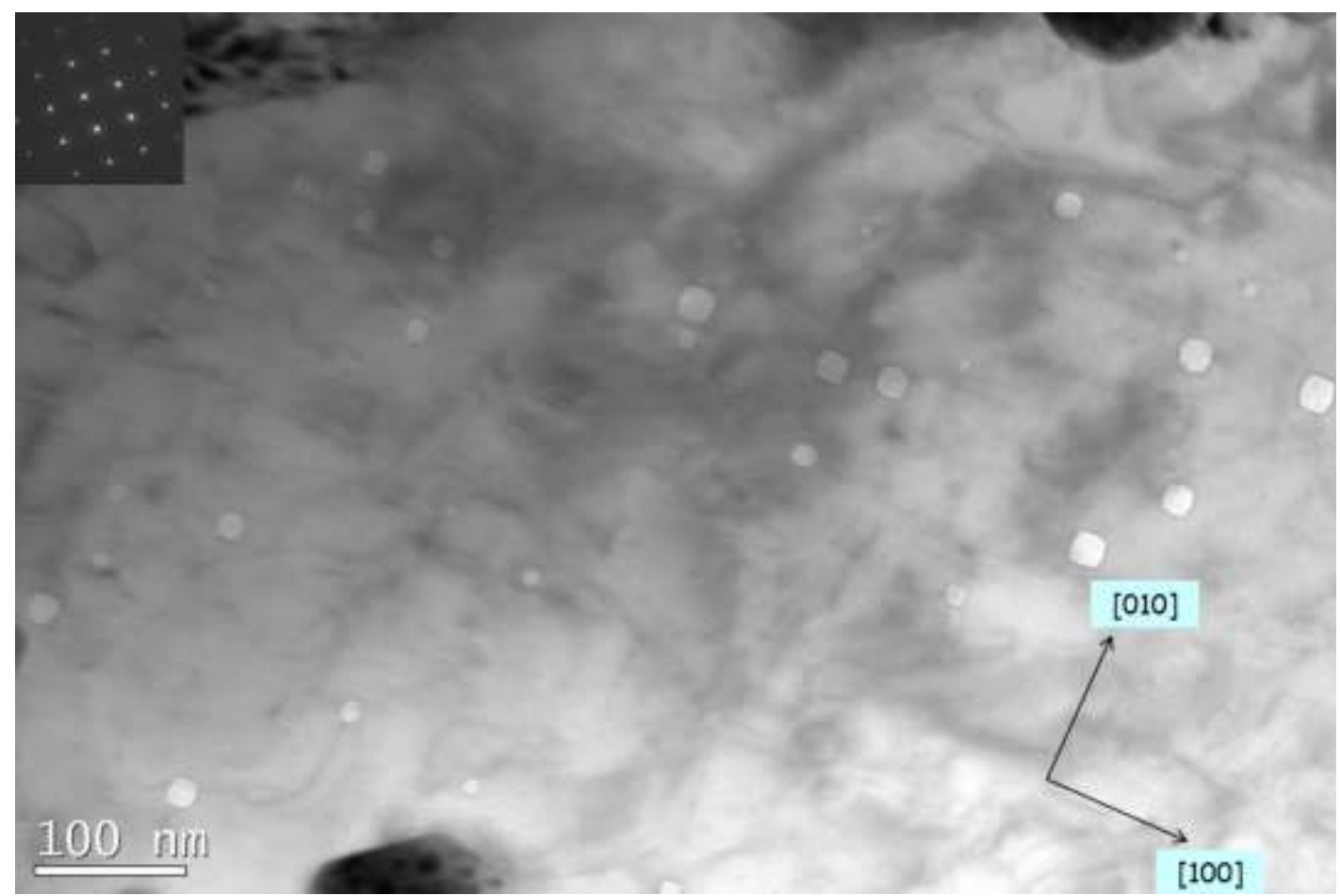

Figure 16: Cavities in EM10 irradiated to 112 dpa at about $398^{\circ} \mathrm{C}$. The investigated area was oriented close to a <001> type zone axis.
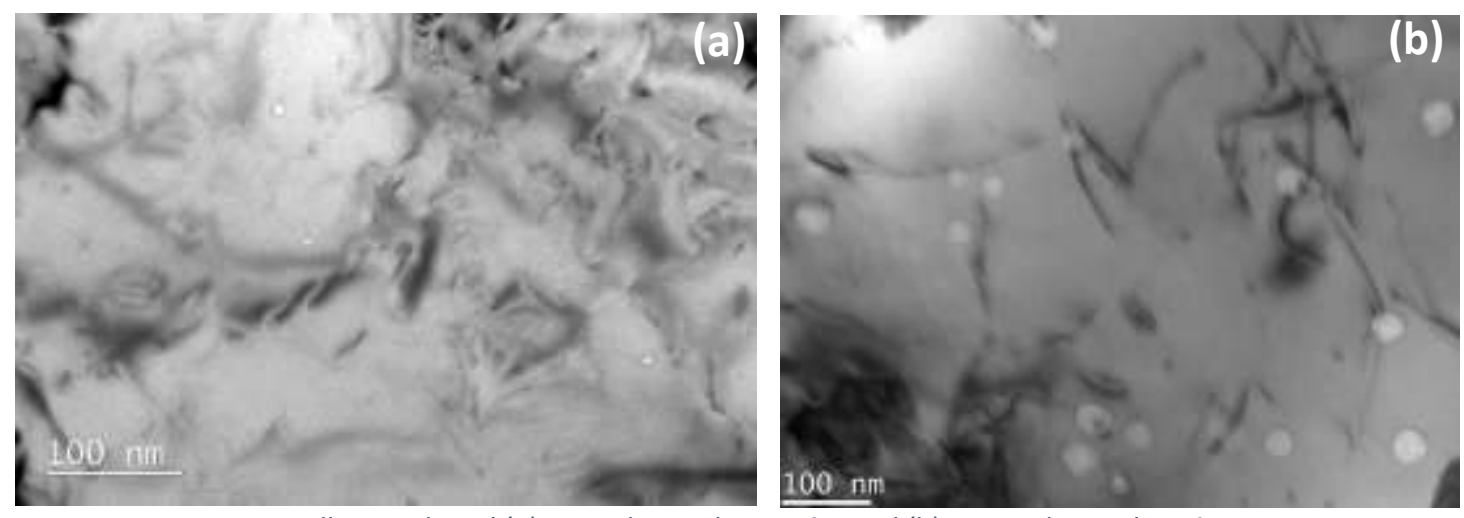

Figure 17: Cavities in EM10 alloy irradiated (a) to $62 \mathrm{dpa}$ and at $386^{\circ} \mathrm{C}$, and (b) to $155 \mathrm{dpa}$ and $439^{\circ} \mathrm{C}$.

Void size distributions and volume fractions were determined for the three irradiations conditions based on measurements performed using several TEM micrographs (whose magnifications were in the range $\times 30000-x 50000$ ), which were recorded from different specimens areas selected at random in order not to select preferentially areas with the highest void densities. The obtained void size distributions and volume fractions are presented in Figure 18 and Table 7. 

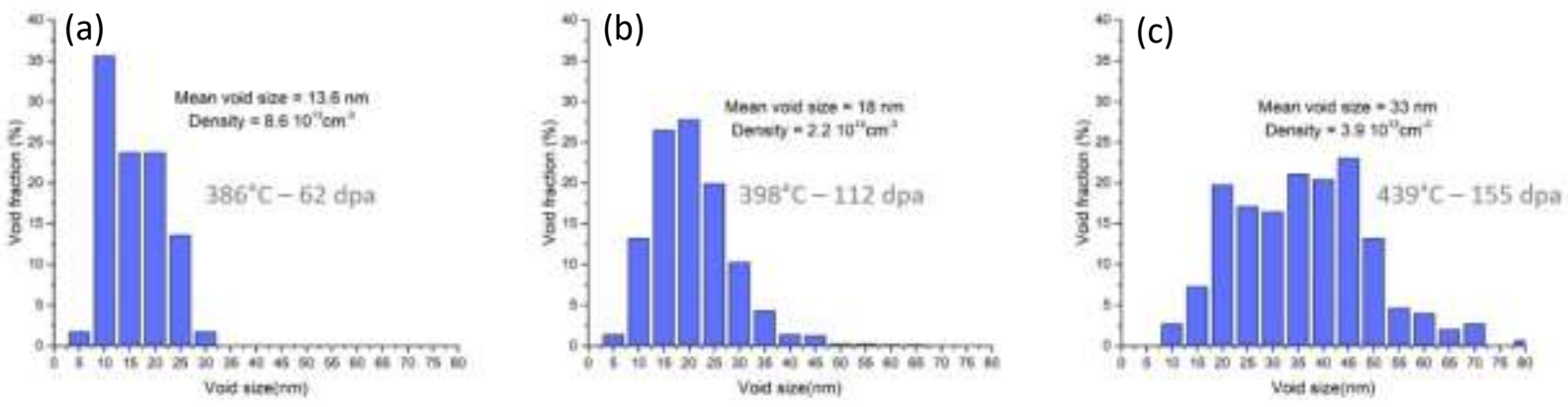

Figure 18: Void size distribution in EM10 irradiated to (a) 62 dpa at $386^{\circ} \mathrm{C}$; (b) 112 dpa at $398^{\circ} \mathrm{C}$; c) 155 dpa at $439^{\circ} \mathrm{C}$

Table 7: Voids sizes and volume fractions measured in EM10 samples extracted from Boitix9 hexagonal ducts irradiated in Phénix.

\begin{tabular}{|c|c|c|c|c|c|c|c|c|c|c|}
\hline \multirow[b]{2}{*}{ Experience } & \multirow[b]{2}{*}{ Stage } & \multirow[b]{2}{*}{ Temperature } & \multirow[b]{2}{*}{ Dose } & \multirow[b]{2}{*}{$\begin{array}{l}\text { Number } \\
\text { of voids }\end{array}$} & \multicolumn{4}{|c|}{ Diameter (nm) } & \multirow[b]{2}{*}{ Density $\left(/ \mathrm{cm}^{3}\right)$} & \multirow[b]{2}{*}{ DeltaV/V(\%) } \\
\hline & & & & & $\min$ & $\max$ & Mean & $\sigma$ & & \\
\hline \multirow{3}{*}{ BOITIX9 } & 7 & $386^{\circ} \mathrm{C}$ & 62 & 59 & 4.5 & 28.7 & 13.6 & 5.6 & $8.610^{13}$ & 0.012 \\
\hline & 8 & $398^{\circ} \mathrm{C}$ & 112 & 946 & 2.7 & 60 & 18.1 & 7.9 & $2.210^{14}$ & 0.11 \\
\hline & 10 & $439^{\circ} \mathrm{C}$ & 155 & 235 & 8 & 78 & 33 & 13 & $3.910^{13}$ & 0.11 \\
\hline
\end{tabular}

One can notice that the values of the void volume fractions measured in the EM10 samples extracted from Boitix9 hexagonal duct are very low (less than $0.1 \%$ ). The void volume fraction obtained using TEM provides a good estimate of the macroscopic swelling. The TEM investigations thus confirmed the results of density measurements, which showed that the swelling of EM10 irradiated up to $155 \mathrm{dpa}$ was negligible. The steel was obviously still in the incubation regime of swelling. Some microstructural findings also support this conclusion, such as the fact that the distribution of cavities was heterogeneous, with zones where no cavities could be detected by TEM, and also the presence of tiny cavities among large voids, indicating that cavity nucleation was still taking place. Furthermore, the void size distribution was narrower at low temperature and dose, meaning that for these conditions nucleation was the predominant mechanism.

The swelling behaviour of FM steels has been extensively studied in the past, however, as underlined for instance by Klueh and Harries [18], it is generally agreed that none of the proposed mechanisms for the high swelling resistance of ferritic steels, which is significantly better than that of austenitic steels for instance, was able to completely explain the experimental data. The mechanisms which have been put forward: i) a higher intrinsic swelling resistance of the BCC crystallographic structure compared to that of the FCC structure (higher self diffusion rates and lower dislocation bias for interstitials), ii) the character of the dislocation loop structure which includes both $\langle 100\rangle$ and $<111\rangle$ type loops, iii) the tempered martensite microstructure which provides a high density of sinks for point defects, iv) the low helium generation rates in FM steels irradiated in a fast fission spectrum.

Concerning the effect of the crystallographic structure, several examples demonstrate that a BCC structure is not sufficient to insure a low swelling behavior. For instance, some studies have evidenced 
a rather high swelling rate in the case of iron, in particular when irradiated with a low damage rate [19]. Another example concerns some vanadium alloys, for which very high swelling rates have been measured, sometimes even greater than those typically observed in the case of alloys with FCC structure [20].

Furthermore, it has been argued, in particular by F. Garner, that the low swelling values generally observed in the case of irradiated FM steels, result primarily from a long transient regime of swelling and that when the transient regime terminates, the steady state swelling rate of FM steels could be about $0.2 \% / \mathrm{dpa}$ [3]. Indeed, ion irradiation experiments of FM steels up to very high doses have shown a steady state swelling regime whose slope was found to be close to $0.2 \% / d p a$ [21].

Furthermore, Figure 19 shows macroscopic swelling values measured for various $9-12 \% \mathrm{Cr}$ FM steels irradiated in fast reactors at temperatures in the range $\left[390-420^{\circ} \mathrm{C}\right]$.

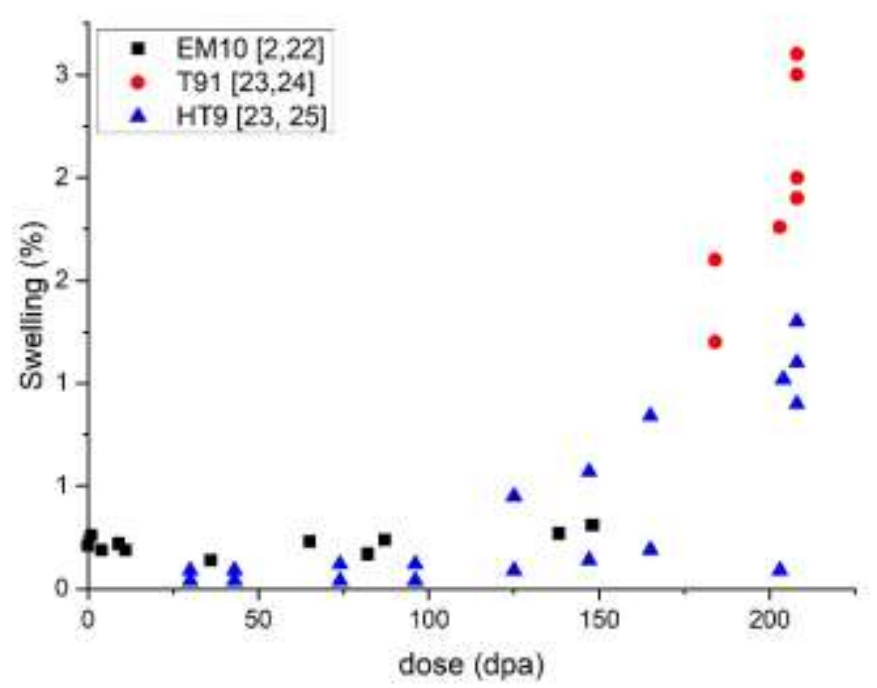

Figure 19: Swelling vs dose for various 9-12\%Cr FM steels (EM10 [2,22]], T91 [23,24], HT9 [23,25]) irradiated at temperatures in the range $\left[390-420^{\circ} \mathrm{C}\right]$.

Although there is a significant data scatter, one can notice an acceleration of swelling for irradiation doses greater than about $150 \mathrm{dpa}$, indicating that some of the investigated steels have probably entered the steady state swelling regime.

\section{Conclusion}

Mechanical tests and microstructural investigations were performed on EM10 irradiated under fast neutrons flux up to $155 \mathrm{dpa}$, as part of the Boitix9 experiment. The mains conclusions are as follows:

- EM10 exhibited a very good mechanical behavior under irradiation to high doses and temperatures (up to $155 \mathrm{dpa}$ and $525^{\circ} \mathrm{C}$ ). Irradiation-induced hardening was found to be low (less than $160 \mathrm{MPa}$ for all investigated conditions) and the DBTT, as measured using subsize Charpy specimens, remained below $10^{\circ} \mathrm{C}$;

- Dimensional stability along the hexagonal tube was noticed ; 
- TEM and density measurements showed the excellent swelling resistance of EM10 at least up to $155 \mathrm{dpa}$;

These findings confirm that EM10 is a suitable wrapper tube material for future advanced sodiumcooled fast neutrons reactors.

\section{Acknowledgements}

The authors wants to thanks P. Coffre, C. Vaille, P. Bottin, D. Schildknecht, D. Conte, V. Pivetaud, B. Bourdiliau, C. Desserouer, B. Arnal, O. Rabouille, C. Mallet and X. Averty for their contributions to this work.

\section{Bibliography}

[1] C. Fazio, P. Dubuisson, Proc. Int. Conf. Fast React. Relat. Fuel Cycles Safe Technol. Sustain. Scenar. 1 (2013) 487.

[2] P. Dubuisson, D. Gilbon, J.L. Séran, Microstructural evolution of ferritic-martensitic steels irradiated in the fast breeder reactor Phénix, J. Nucl. Mater. 205 (1993) 178-189. https://doi.org/10.1016/0022-3115(93)90080-I.

[3] F.A. Garner, M.B. Toloczko, B.H. Sencer, Comparison of swelling and irradiation creep behavior of fcc-austenitic and bcc-ferritic/martensitic alloys at high neutron exposure, J. Nucl. Mater. 276 (2000) 123-142. https://doi.org/10.1016/S0022-3115(99)00225-1.

[4] J.L. Séran, A. Alamo, A. Maillard, H. Touron, J.C. Brachet, P. Dubuisson, O. Rabouille, Pre- and post-irradiation mechanical properties of ferritic-martensitic steels for fusion applications: EM10 base metal and EM10/EM10 welds, J. Nucl. Mater. 212 (1994) 588-593. https://doi.org/10.1016/0022-3115(94)90128-7.

[5] J. Henry, X. Averty, A. Alamo, Tensile and impact properties of $9 \mathrm{Cr}$ tempered martensitic steels and ODS-FeCr alloys irradiated in a fast reactor at $325^{\circ} \mathrm{C}$ up to $78 \mathrm{dpa}$, J. Nucl. Mater. 417 (2011) 99-103. https://doi.org/10.1016/j.jnucmat.2010.12.203.

[6] J.L. Séran, V. Lévy, D. Gilbon, A. Maillard, A. Fissolo, H. Touron, R. Cauvin, A. Chalony, E.L. Boulbin, Behavior under Neutron Irradiation of the 15-15Ti and EM10 Steels Used as Standard Materials of the Phénix Fuel Subassembly, Eff. Radiat. Mater. 15th Int. Symp. (1992). https://doi.org/10.1520/STP17941S.

[7] A. Alamo, J.L. Bertin, V.K. Shamardin, P. Wident, Mechanical properties of $9 \mathrm{Cr}$ martensitic steels and ODS-FeCr alloys after neutron irradiation at $325^{\circ} \mathrm{C}$ up to $42 \mathrm{dpa}$, J. Nucl. Mater. $367-370$ (2007) 54-59. https://doi.org/10.1016/j.jnucmat.2007.03.166.

[8] A. Alamo, M. Horsten, X. Averty, E.I. Materna-Morris, M. Rieth, J.C. Brachet, Mechanical behavior of reduced-activation and conventional martensitic steels after neutron irradiation in the range $250-450^{\circ} \mathrm{C}$, J. Nucl. Mater. 283-287 (2000) 353-357. https://doi.org/10.1016/S00223115(00)00076-3.

[9] Y. de Carlan, X. Averty, J.-C. Brachet, J.-L. Bertin, F. Rozenblum, O. Rabouille, A. Bougault, PostIrradiation Tensile Behavior and Residual Activity of Several Ferritic/Martensitic and Austenitic Steels Irradiated in Osiris Reactor at $325^{\circ} \mathrm{C}$ up to 9 dpa, J. ASTM Int. 2 (2005) 1-19. https://doi.org/10.1520/JAl12354.

[10] J.-C. Brachet, A. Castaing, C. Foucher, Int. Symp. Mater. Ageing Compon. Life Ext. 75 (1995).

[11] M. Wall, B.C. Edwards, J.A. Hudson, in: Chester U.K., 1983: p. 260/2.

[12] F.W. Noble, B.A. Senior, B.L. Eyre, The effect of phosphorus on the ductility of $9 \mathrm{Cr}-1 \mathrm{Mo}$ steels, Acta Metall. Mater. 38 (1990) 709-717. https://doi.org/10.1016/0956-7151(90)90022-9.

[13] A. Alamo, J.-C. Brachet, A. Castaing, C. Foucher, Miner. Met. Mater. Soc. (1996) 121. 
[14] D. Gilbon, C. Rivera, O. Rabouille, Stabilité microstructurale de l'EM10 irradié dans Phénix : examens MET des étages 2, 8, 10 et 14 du TH de SPHINX 5, CEA Saclay, 1990.

[15] T.S. Byun, W. Daniel Lewis, M.B. Toloczko, S.A. Maloy, Impact properties of irradiated HT9 from the fuel duct of FFTF, J. Nucl. Mater. 421 (2012) 104-111. https://doi.org/10.1016/j.jnucmat.2011.11.059.

[16] S.L. Dudarev, J.-L. Boutard, R. Lässer, M.J. Caturla, P.M. Derlet, M. Fivel, C.-C. Fu, M.Y. Lavrentiev, L. Malerba, M. Mrovec, D. Nguyen-Manh, K. Nordlund, M. Perlado, R. Schäublin, H. Van Swygenhoven, D. Terentyev, J. Wallenius, D. Weygand, F. Willaime, The EU programme for modelling radiation effects in fusion reactor materials: An overview of recent advances and future goals, J. Nucl. Mater. 386-388 (2009) 1-7. https://doi.org/10.1016/j.jnucmat.2008.12.301.

[17] M.L. Jenkins, Z. Yao, M. Hernández-Mayoral, M.A. Kirk, Dynamic observations of heavy-ion damage in Fe and Fe-Cr alloys, J. Nucl. Mater. 389 (2009) 197-202. https://doi.org/10.1016/j.jnucmat.2009.02.003.

[18] R.L. Klueh, D.R. Harries, High-chromium ferritic and martensitic steels for nuclear applications, ASTM, W. Conshohocken, PA, 2001.

[19] N.I. Budylkin, E.G. Mironova, V.M. Chernov, V.A. Krasnoselov, S.I. Porollo, F.A. Garner, Neutroninduced swelling and embrittlement of pure iron and pure nickel irradiated in the BN-350 and BOR-60 fast reactors, J. Nucl. Mater. 375 (2008) 359-364. https://doi.org/10.1016/j.jnucmat.2008.01.015.

[20] F.A. Garner, D.S. Gelles, H. Takahashi, S. Ohnuki, H. Kinoshita, B.A. Loomis, High swelling rates observed in neutron-irradiated V-Cr and V-Si binary alloys, J. Nucl. Mater. 191 (1992) 948-951. https://doi.org/10.1016/0022-3115(92)90613-P.

[21] Y.E. Kupriiyanova, V.V. Bryk, O.V. Borodin, A.S. Kalchenko, V.N. Voyevodin, G.D. Tolstolutskaya, F.A. Garner, Use of double and triple-ion irradiation to study the influence of high levels of helium and hydrogen on void swelling of $8-12 \% \mathrm{Cr}$ ferritic-martensitic steels, J. Nucl. Mater. 468 (2016) 264-273. https://doi.org/10.1016/j.jnucmat.2015.07.012.

[22] L. Belin, C. Rabourg, G.M. Decroix, X. Averty, 2003.

[23] M.B. Toloczko, F.A. Garner, C.R. Eiholzer, Irradiation creep and swelling of the US fusion heats of HT9 and 9Cr-1Mo to $208 \mathrm{dpa}$ at $\sim 400^{\circ} \mathrm{C}$, J. Nucl. Mater. 212 (1994) 604-607. https://doi.org/10.1016/0022-3115(94)90131-7.

[24] J. Van den Bosch, O. Anderoglu, R. Dickerson, M. Hartl, P. Dickerson, J.A. Aguiar, P. Hosemann, M.B. Toloczko, S.A. Maloy, SANS and TEM of ferritic-martensitic steel T91 irradiated in FFTF up to $184 \mathrm{dpa}$ at $413^{\circ} \mathrm{C}$, J. Nucl. Mater. 440 (2013) 91-97. https://doi.org/10.1016/j.jnucmat.2013.04.025.

[25] D.S. Gelles, Microstructural examination of commercial ferritic alloys at $200 \mathrm{dpa}$, J. Nucl. Mater. 233-237, Part 1 (1996) 293-298. https://doi.org/10.1016/S0022-3115(96)00222-X. 